Nevada

Environmental

Restoration

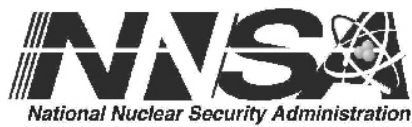

Project

\title{
Corrective Action Plan for
} Corrective Action Unit 166: Storage Yards and Contaminated Materials, Nevada Test Site, Nevada

Controlled Copy No::

Revision: 0

October 2007

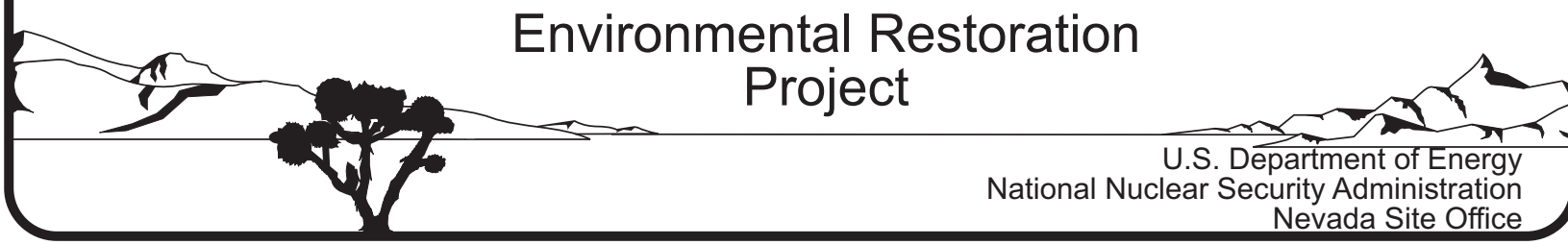




\title{
DISCLAIMER
}

Reference herein to any specific commercial product, process, or service by trade name, trademark, manufacturer, or otherwise, does not necessarily constitute or imply its endorsement, recommendation, or favoring by the United States Government or any agency thereof or its contractors or subcontractors.

This report has been reproduced directly from the best available copy.

Available for sale to the public from:

\author{
U.S. Department of Commerce \\ National Technical Information Service \\ 5285 Port Royal Road \\ Springfield, VA 22161-0002 \\ Telephone: (800) 553-6847 \\ Fax: (703) 605-6900 \\ E-mail: orders@ntis.gov \\ Online ordering: http://www.ntis.gov/ordering.htm
}

Available electronically at http://www.osti.gov/bridge.

Available for a processing fee to the U.S. Department of Energy and its contractors, in paper, from:

U.S. Department of Energy

Office of Scientific and Technical Information

P.O. Box 62

Oak Ridge, TN 37831-0062

Telephone: (865) 576-8401

Fax: (865) 576-5728

E-mail: reports@adonis.osti.gov 


\title{
CORRECTIVE ACTION PLAN FOR CORRECTIVE ACTION UNIT 166: STORAGE YARDS AND CONTAMINATED MATERIALS, NEVADA TEST SITE, NEVADA
}

\author{
U.S. Department of Energy \\ National Nuclear Security Administration \\ Nevada Site Office \\ Las Vegas, Nevada
}

Controlled Copy No.

Revision: 0

October 2007 
THIS PAGE INTENTIONALLY LEFT BLANK 


\section{CORRECTIVE ACTION PLAN FOR CORRECTIVE ACTION UNIT 166: STORAGE YARDS AND CONTAMINATED MATERIALS, NEVADA TEST SITE, NEVADA}

Kevin J. Cabble

Federal Sub-Project Director

Industrial Sites Sub-Project

Approved By: SIGNATURE APPROVED

Date: $\underline{10 / 03 / 2007}$

John B. Jones

Acting Federal Project Director

Environmental Restoration Project 
THIS PAGE INTENTIONALLY LEFT BLANK 


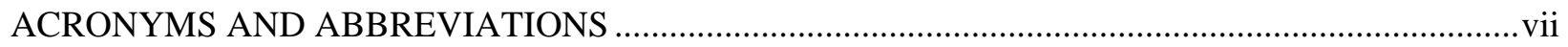

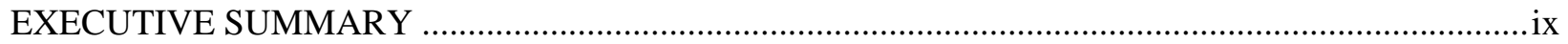

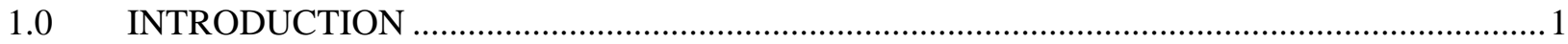

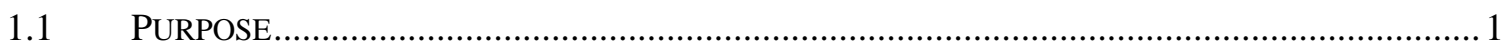

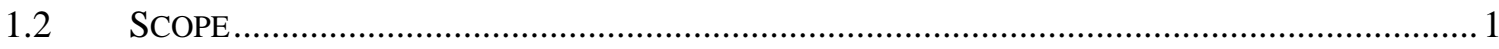

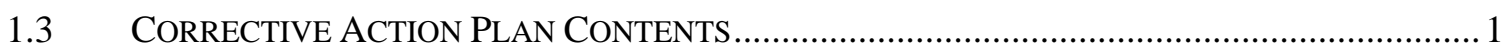

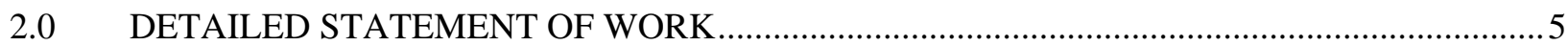

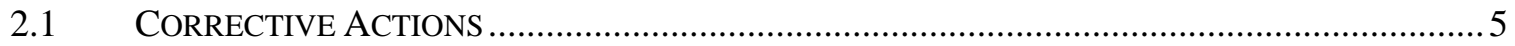

2.1.1 Alternative 1, No Further Action ....................................................................... 5

2.1.1.1 Corrective Action Site 02-42-01, Cond. Release

Storage Yd - North ........................................................................... 5

2.1.1.2 Corrective Action Site 02-42-02, Cond. Release Storage Yd - South ........................................................................... 5

2.1.1.3 Corrective Action Site 05-19-02, Contaminated Soil and Drum.......... 6

2.1.1.4 Corrective Action Site 18-99-03, Wax Piles/Oil Stain .......................... 6

2.1.2 Alternative 2, Clean Closure...................................................................... 9

2.1.2.1 Corrective Action Site 02-99-10, D-38 Storage Area ......................... 9

2.1.2.2 Corrective Action Site 03-42-01, Conditional Release Storage Yard................................................................................ 11

2.1.2.3 Corrective Action Site 18-01-01, Aboveground Storage Tank ..........11

2.2 CONSTRUCTION QUALITY ASSURANCE/QUALITY CONTROL ........................................ 14

2.2.1 Construction Field Sample Collection Activities ................................................ 14

2.2.2 Construction Laboratory/Analytical Data Quality Indicators ............................... 14

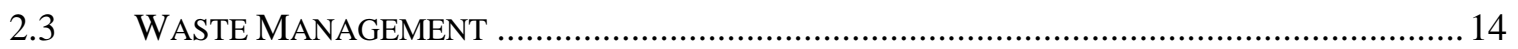

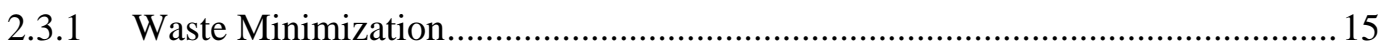

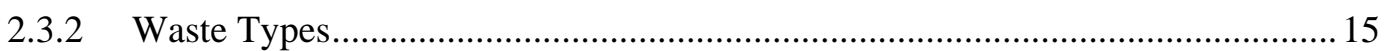

2.3.2.1 Sanitary Waste and Construction Debris........................................... 15

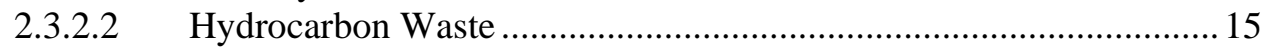

2.3.2.3 Hazardous Waste ............................................................................. 15

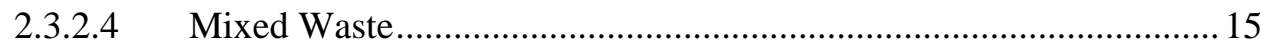

2.3.2.5 Asbestos-Containing Material ......................................................... 16

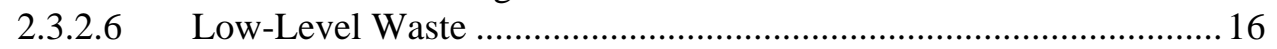

2.3.2.7 Toxic Substances Control Act-Regulated Waste ................................16

2.3.2.8 Decontamination Waste...............................................................16

2.3.2.9 Personal Protective Equipment............................................................ 16

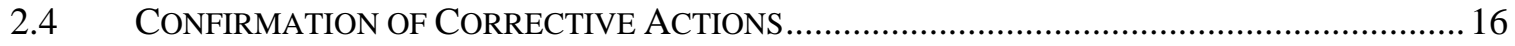

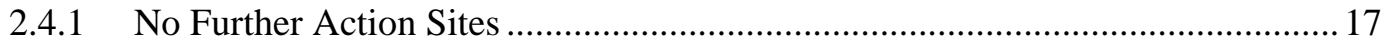

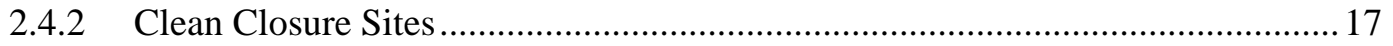

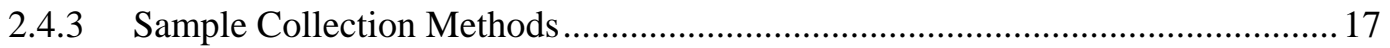

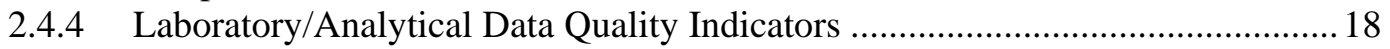

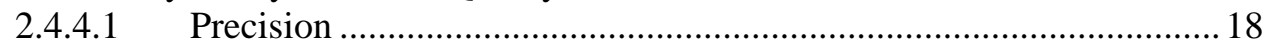

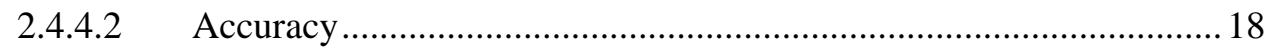

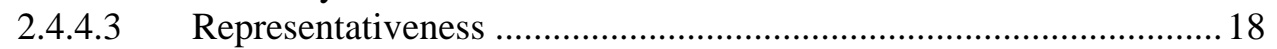

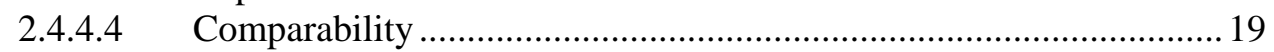

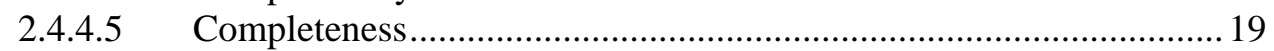

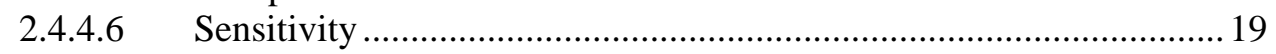

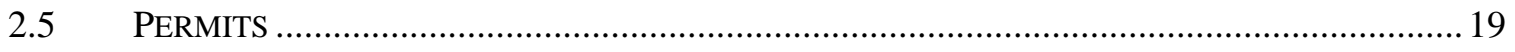


2.5.1 National Environmental Policy Act Checklist ................................................. 19

2.5.2 Real Estate/Operations Permit ...................................................................... 19

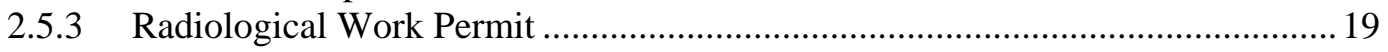

2.5.4 Utility Clearances, Excavation Permits, and Blind Penetration Permits .............. 20

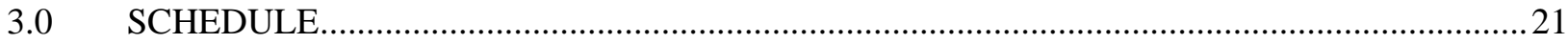

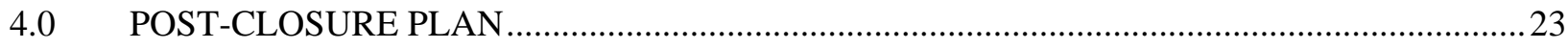

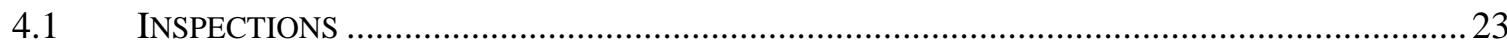

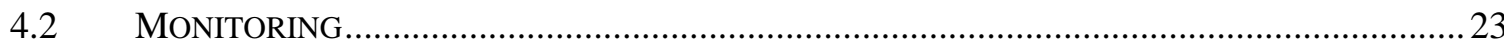

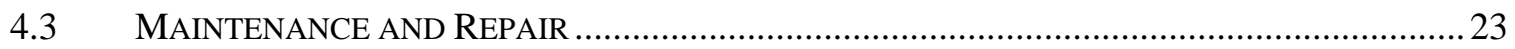

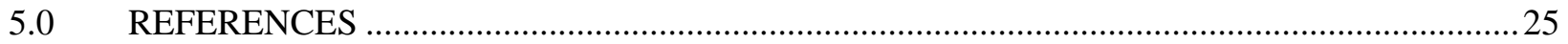

LIBRARY DISTRIBUTION LIST

\section{LIST OF FIGURES}

Figure 1. Corrective Action Unit 166 Site Location MaP .............................................. 2

Figure 2. Corrective Action Site 05-19-02, ContAminated Soil AND Drum ...................... 7

Figure 3. Corrective Action Site 18-99-03, Wax Piles/Oil Stain ...................................... 8

Figure 4. Corrective Action Site 02-99-10, D-38 StORAGE AREA ...................................... 10

Figure 5. Corrective Action Site 03-42-01, Conditional Release StORAGE Yard .......... 12

Figure 6. Corrective Action Site 18-01-01, AbOveground StORAge TANK ...................... 13

\section{LIST OF TABLES}

Table 1. Corrective Action Unit 166 Closure Activities ................................................. 3

\section{LIST OF APPENDICES}

APPENDIX A.1. ENGINEERING SPECIFICATIONS AND DRAWINGS....................................... A.1-1

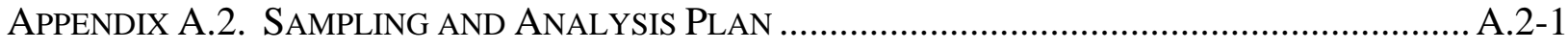

ApPendix A.3. Project ORganization........................................................................ A.3-1 


\section{ACRONYMS AND ABBREVIATIONS}

\begin{tabular}{|c|c|}
\hline ACM & asbestos-containing material \\
\hline Am & americium \\
\hline bgs & below ground surface \\
\hline BMP & best management practice \\
\hline CA & Contamination Area \\
\hline CADD & Corrective Action Decision Document \\
\hline CAIP & Corrective Action Investigation Plan \\
\hline CAP & Corrective Action Plan \\
\hline CAS & Corrective Action Site \\
\hline CAU & Corrective Action Unit \\
\hline $\mathrm{COC}$ & contaminant of concern \\
\hline CR & Closure Report \\
\hline DOE & U.S. Department of Energy \\
\hline DOT & U.S. Department of Transportation \\
\hline DQI & data quality indicator \\
\hline DQO & data quality objective \\
\hline EPA & U.S. Environmental Protection Agency \\
\hline FAL & final action level \\
\hline FFACO & Federal Facility Agreement and Consent Order \\
\hline $\mathrm{ft}$ & foot (feet) \\
\hline gal & gallon(s) \\
\hline HW & hazardous waste \\
\hline LLNL & Lawrence Livermore National Laboratory \\
\hline LLW & low-level waste \\
\hline $\mathrm{mg} / \mathrm{kg}$ & milligram(s) per kilogram \\
\hline $\mathrm{mg} / \mathrm{L}$ & milligram(s) per liter \\
\hline MW & mixed waste \\
\hline NDEP & Nevada Division of Environmental Protection \\
\hline NEPA & National Environmental Policy Act \\
\hline NNSA/NSO & $\begin{array}{l}\text { U.S. Department of Energy, National Nuclear Security Administration } \\
\text { Nevada Site Office }\end{array}$ \\
\hline
\end{tabular}




\section{ACRONYMS AND ABBREVIATIONS (continued)}

NNSA/NV

NTS

$\% \mathrm{R}$

PAL

$\mathrm{pCi} / \mathrm{g}$

PPE

$\mathrm{Pu}$

$\mathrm{QA} / \mathrm{QC}$

RPD

REOP

RWP

$\mathrm{TPH}$

TSCA

$\mathrm{yd}^{3}$
U.S. Department of Energy, National Nuclear Security Administration Nevada Operations Office

Nevada Test Site

percent recovery

preliminary action level

picocurie(s) per gram

personal protective equipment

plutonium

quality assurance/quality control

relative percentage difference

Real Estate/Operations Permit

Radiological Work Permit

total petroleum hydrocarbons

Toxic Substances Control Act

cubic yard(s) 
Corrective Action Unit (CAU) 166, Storage Yards and Contaminated Materials, is listed in the Federal Facility Agreement and Consent Order (FFACO) of 1996 (FFACO, 1996). CAU 166 consists of seven Corrective Action Sites (CASs) located in Areas 2, 3, 5, and 18 of the Nevada Test Site, which is located approximately 65 miles northwest of Las Vegas, Nevada. CAU 166 consists of the following CASs:

- CAS 02-42-01, Cond. Release Storage Yd - North

- CAS 02-42-02, Cond. Release Storage Yd - South

- CAS 02-99-10, D-38 Storage Area

- CAS 03-42-01, Conditional Release Storage Yard

- CAS 05-19-02, Contaminated Soil and Drum

- CAS 18-01-01, Aboveground Storage Tank

- CAS 18-99-03, Wax Piles/Oil Stain

Site characterization of the CAU 166 CASs was performed in 2006 and 2007, and the results are presented in Appendix A of the CAU 166 Corrective Action Decision Document (U.S. Department of Energy, National Nuclear Security Administration Nevada Site Office, 2007). The scope of work required to implement the recommended closure alternatives is summarized below.

- CAS 02-42-01, Cond. Release Storage Yd - North, contains no contaminants of concern (COCs) above final action levels (FALs). No further action is required for this site, and no work will be performed.

- CAS 02-42-02, Cond. Release Storage Yd - South, contains no COCs above FALs. No further action is required for this site, and no work will be performed.

- CAS 02-99-10, D-38 Storage Area, will be clean closed by removing approximately 40 gallons (gal) of lead shot for likely offsite disposal as hazardous waste (HW).

- CAS 03-42-01, Conditional Release Storage Yard, will be clean closed by removing approximately 5 cubic yards $\left(\mathrm{yd}^{3}\right)$ of soil impacted with americium-241 and lead for likely offsite disposal as mixed waste. In addition, as a best management practice (BMP), asbestos tile will be removed from a portable building, and oil will be removed from three accumulator assemblies and characterized as necessary for proper disposal. The portable building and assemblies will then be removed for disposal as sanitary waste. A gas cylinder will also be removed for proper disposal.

- CAS 05-19-02, Contaminated Soil and Drum, contains no COCs above FALs. No further action is required for this site; however, as a BMP, an empty drum will be removed for disposal as sanitary waste.

- CAS 18-01-01, Aboveground Storage Tank, will be clean closed by removing approximately 600 gal of lead-impacted liquid from a metal container for likely offsite disposal as HW. In addition, as a BMP, approximately $0.4 \mathrm{yd}^{3}$ of wax will be removed for likely disposal as hydrocarbon waste, approximately 30 gal of liquid in a second metal container will either be removed for disposal as sanitary waste or solidified in place, and the two metal containers will be grouted in place. 


\section{EXECUTIVE SUMMARY (continued)}

- CAS 18-99-03, Wax Piles/Oil Stain, contains no COCs above FALs. No further action is required for this site; however, as a BMP, approximately $2.2 \mathrm{yd}^{3}$ of wax will be removed for likely disposal as hydrocarbon waste, approximately 30 gal of liquid in a metal container will either be removed for disposal as sanitary waste or solidified in place, and the metal container will be grouted in place. 


\subsection{INTRODUCTION}

Corrective Action Unit (CAU) 166, Storage Yards and Contaminated Materials, is listed in the Federal Facility Agreement and Consent Order (FFACO) of 1996 (FFACO, 1996). CAU 166 consists of seven Corrective Action Sites (CASs) located in Areas 2, 3, 5, and 18 of the Nevada Test Site (NTS), which is located approximately 65 miles northwest of Las Vegas, Nevada (Figure 1). CAU 166 consists of the following CASs:

- CAS 02-42-01, Cond. Release Storage Yd - North

- CAS 02-42-02, Cond. Release Storage Yd - South

- CAS 02-99-10, D-38 Storage Area

- CAS 03-42-01, Conditional Release Storage Yard

- CAS 05-19-02, Contaminated Soil and Drum

- CAS 18-01-01, Aboveground Storage Tank

- CAS 18-99-03, Wax Piles/Oil Stain

Details of the site history and site characterization results for CAU 166 are provided in the approved Corrective Action Investigation Plan (CAIP) (U.S. Department of Energy, National Nuclear Security Administration Nevada Site Office [NNSA/NSO], 2006) and in the approved Corrective Action Decision Document (CADD) (NNSA/NSO, 2007).

\subsection{Purpose}

The purpose of this Corrective Action Plan (CAP) is to present the detailed scope of work required to implement the recommended corrective actions as specified in Section 4.0 of the approved CADD (NNSA/NSO, 2007).

\subsection{SCOPE}

The approved closure activities for CAU 166 include removal of lead shot, soil contaminated with americium (Am)-241 and lead, and liquid impacted with lead for proper disposal. As best management practices (BMPs), asbestos tile, oil, a portable building, accumulator assemblies, an empty drum, wax, and liquid will be removed and characterized as necessary for proper disposal. Table 1 presents a summary of CAS-specific closure activities and contaminants of concern (COCs). Specific details of the corrective actions to be performed at each CAS are presented in Section 2.0 of this report.

\subsection{Corrective Action Plan Contents}

This CAP consists of the following sections and appendices:

- Section 1.0: Introduction

- Section 2.0: Detailed Statement of Work

- Section 3.0: Schedule

- Section 4.0: Post-Closure Plan

- Section 5.0: References 


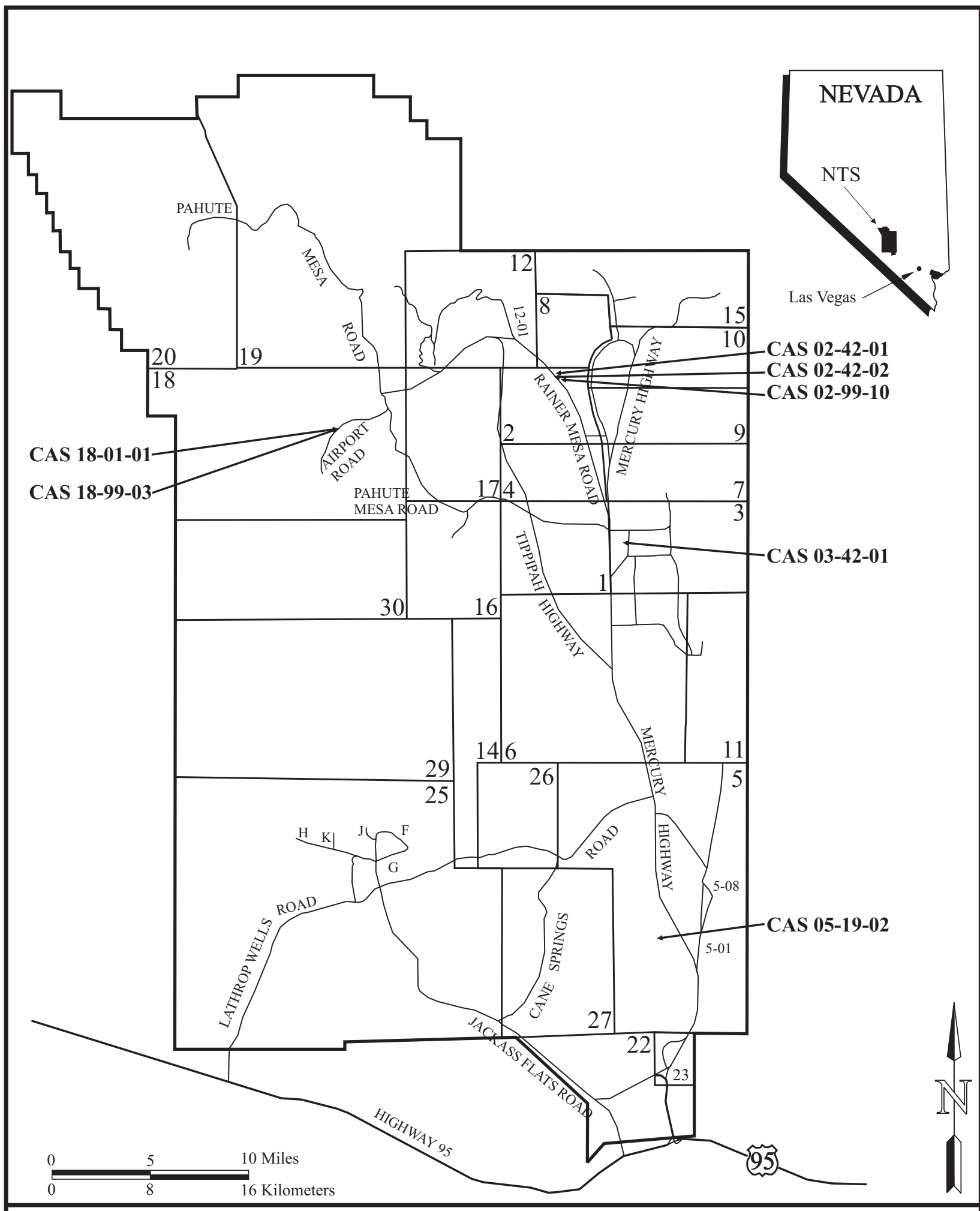

Figure 1. Corrective ACtion Unit 166 Site Location MaP 
Table 1. Corrective Action Unit 166 Closure Activities

\begin{tabular}{|c|c|c|c|c|}
\hline CAS & Name & Closure Method & COCs & Scope of Work \\
\hline $02-42-01$ & Cond. Release Storage Yd - North & No Further Action & None & None \\
\hline $02-42-02$ & Cond. Release Storage Yd - South & No Further Action & None & None \\
\hline 02-99-10 & D-38 Storage Area & Clean Closure & $\begin{array}{l}\text { Lead } \\
\text { Arsenic }\end{array}$ & $\begin{array}{l}\text { - Remove approximately } 40 \text { gal of lead shot for likely offsite disposal as } \\
\text { hazardous waste }\end{array}$ \\
\hline $03-42-01$ & Conditional Release Storage Yard & Clean Closure & $\begin{array}{l}\text { Am-241 } \\
\text { Lead }\end{array}$ & $\begin{array}{l}\text { - } \text { Remove approximately } 5 \mathrm{yd}^{3} \text { of soil contaminated with Am-241 and } \\
\text { lead for likely offsite disposal as mixed waste } \\
\text { - } \quad \text { Collect verification samples and backfill excavation } \\
\text { - } \text { As a BMP, remove asbestos tile from a portable building for disposal } \\
\text { - } \text { As a BMP, remove oil from three accumulator assemblies for } \\
\text { characterization and disposal } \\
\text { - As a BMP, remove portable building and accumulator assemblies for } \\
\text { disposal as sanitary waste } \\
\text { - As a BMP, remove a gas cylinder for disposal }\end{array}$ \\
\hline 05-19-02 & Contaminated Soil and Drum & No Further Action & None & - As a BMP, remove an empty drum for disposal as sanitary waste \\
\hline $18-01-01$ & Aboveground Storage Tank & Clean Closure & Lead & $\begin{array}{l}\text { - Remove approximately } 600 \text { gal of lead-impacted liquid for likely } \\
\text { offsite disposal as hazardous waste } \\
\text { - As a BMP, remove approximately } 0.4 \mathrm{yd}^{3} \text { of wax for likely disposal as } \\
\text { hydrocarbon waste } \\
\text { - As a BMP, either remove for disposal as sanitary waste or solidify in } \\
\text { place approximately } 30 \text { gal of liquid } \\
\text { - As a BMP, grout two metal containers in place }\end{array}$ \\
\hline $18-99-03$ & Wax Piles/Oil Stain & No Further Action & None & $\begin{array}{l}\text { - As a BMP, remove approximately } 2.2 \mathrm{yd}^{3} \text { of wax for likely disposal as } \\
\text { hydrocarbon waste } \\
\text { - As a BMP, either remove for disposal as sanitary waste or solidify in } \\
\text { place approximately } 30 \text { gal of liquid } \\
\text { - As a BMP, grout a metal container in place }\end{array}$ \\
\hline $\begin{array}{l}\text { Am: amer } \\
\text { BMP: bes } \\
\text { CAS: Cor }\end{array}$ & $\begin{array}{l}\text { lum } \\
\text { management practice } \\
\text { ctive Action Site }\end{array}$ & $\begin{array}{l}\text { COC: contaminant of ce } \\
\text { gal: gallon(s) } \\
\text { ydd }^{3}: \text { cubic yard(s) }\end{array}$ & & \\
\hline
\end{tabular}


- Appendix A.1: Engineering Specifications and Drawings

- Appendix A.2: Sampling and Analysis Plan

- Appendix A.3: Project Organization

- Library Distribution List

Appendix A.1 is included in this CAP as required by the approved FFACO outline, but contains no material because engineering specifications or drawings are not required for closure of CAU 166. Similarly, Appendix A.2 is included as required but contains no material. Sufficient detail on the type, number, and location of verification samples to be collected to verify site closure activities has been provided in Section 2.4 of this report. 


\subsection{DETAILED STATEMENT OF WORK}

The approved corrective actions, as evaluated in Section 3.0 of the CADD and identified in Section 4.0 of the CADD (NNSA/NSO, 2007) for CAU 166, include:

- CAS 02-42-01, Cond. Release Storage Yd - North: No Further Action

- CAS 02-42-02, Cond. Release Storage Yd - South: No Further Action

- CAS 02-99-10, D-38 Storage Area: Clean Closure

- CAS 03-42-01, Conditional Release Storage Yard: Clean Closure

- CAS 05-19-02, Contaminated Soil and Drum: No Further Action

- CAS 18-01-01, Aboveground Storage Tank: Clean Closure

- CAS 18-99-03, Wax Piles/Oil Stain: No Further Action

\subsection{Corrective ACtions}

The corrective action alternatives for CAU 166 are identified in Section 4.0 of the CADD (NNSA/NSO, 2007) and were approved by the Nevada Division of Environmental Protection (NDEP). The objective of the corrective actions is to prevent or mitigate adverse environmental impacts and migration of contamination. The corrective actions and BMPs for CAU 166 are identified below.

\subsubsection{Alternative 1, No Further Action}

\subsubsection{Corrective Action Site 02-42-01, Cond. Release Storage Yd - North}

This site is located in Area 2 of the NTS, northeast of the intersection of Rainier Mesa and 2-07 Roads in the former Area 2 Camp. The camp supported the Lawrence Livermore National Laboratory (LLNL) drilling and construction activities in the Yucca Flat area. The site consists of a storage yard where various machinery and equipment were stored.

No COCs are present at concentrations above final action levels (FALs) at this site. No further action is required for this site, and no work will be performed.

\subsubsection{Corrective Action Site 02-42-02, Cond. Release Storage Yd - South}

This site is located in Area 2 of the NTS, southwest of the intersection of Rainier Mesa and 2-07 Roads in the former Area 2 Camp. The camp supported the LLNL drilling and construction activities in the Yucca Flat area. The site consists of a storage yard where various machinery and equipment were stored. Gas sampling tanks also may have been temporarily stored at the site.

No COCs are present at concentrations above FALs at this site. No further action is required for this site, and no work will be performed. 


\subsubsection{Corrective Action Site 05-19-02, Contaminated Soil and Drum}

This site is located in Area 5 of the NTS, in a remote area near a dirt road approximately 1.4 miles west of Mercury Highway, and is associated with Operation Ranger, a series of atmospheric tests that took place in 1951. The site consists of a fenced storage yard where vehicles were stored and an adjacent area where 17 drums were stored. The three vehicles that remain in the yard were placed there to allow induced radioactivity to decay. Other steel debris also remains at the site, and an empty drum is present in the wash adjacent to the yard. The vehicles and steel have been determined to have historical significance. Figure 2 shows a site sketch of the CAS.

No COCs are present at concentrations above FALs at this site. No further action is required for this site; however, as a BMP, the empty drum will be removed for disposal as sanitary waste.

\subsubsection{Corrective Action Site 18-99-03, Wax Piles/Oil Stain}

This site is located near the airstrip in Area 18 of the NTS, southeast of the Little Feller II site. The site consists of a metal container containing wax and liquid, a metal box, and two wax piles. The containers and wax piles are believed to be part of the neutron flux experiments associated with the Little Feller II test that took place in 1962. A portion of the site is located within a fenced Contamination Area (CA). Figure 3 shows a site sketch of the CAS. Surface soil impacted by contamination associated with atmospheric testing is not associated with a release from CAU 166 and will be addressed by the Soils Project.

The metal container is located outside of the fenced CA and sits on a steel plate and concrete base. The metal container has four compartments with four concrete-encased, closed-ended subsurface pipes that extend from its base to 4 feet (ft) below ground surface (bgs). One of the subsurface pipes contained liquid while the other three pipes were plugged with wax. During site characterization activities, the wax plugs were removed, and liquid was found in the pipes beneath the wax plugs. A wax pile is located adjacent to the metal container.

The metal box, located within the CA, is $3 \mathrm{ft}$ by $3 \mathrm{ft}$, is sitting on top of a soil mound, and has wax on and adjacent to its south side. A wax pile is located northwest of the metal box and soil mound, also within the CA.

Total petroleum hydrocarbons (TPH) were detected in two characterization soil samples at concentrations above the preliminary action level (PAL) of 100 milligrams per kilogram (mg/kg). The maximum concentration of TPH detected was $490 \mathrm{mg} / \mathrm{kg}$. TPH was also present at concentrations above the FAL in all three wax samples that were analyzed for TPH. The maximum concentration of TPH detected in the wax samples was 92,000 mg/kg. FALs were established for the hazardous constituents of TPH at their respective PAL concentrations, and none of the hazardous constituents of TPH exceeded the PALs. Therefore, TPH is not considered a COC for this site.

Am-241 was detected in nine characterization soil samples at concentrations above its FAL of 12.7 picocuries per gram (pCi/g). The maximum concentration of Am-241 detected was 1,130 pCi/g. Plutonium (Pu)-238 was detected in four characterization soil samples at concentrations above its FAL of $13 \mathrm{pCi} / \mathrm{g}$. The maximum concentration of Pu-238 was $101 \mathrm{pCi} / \mathrm{g}$. Pu-239/240 was detected in eight characterization soil samples at concentrations 


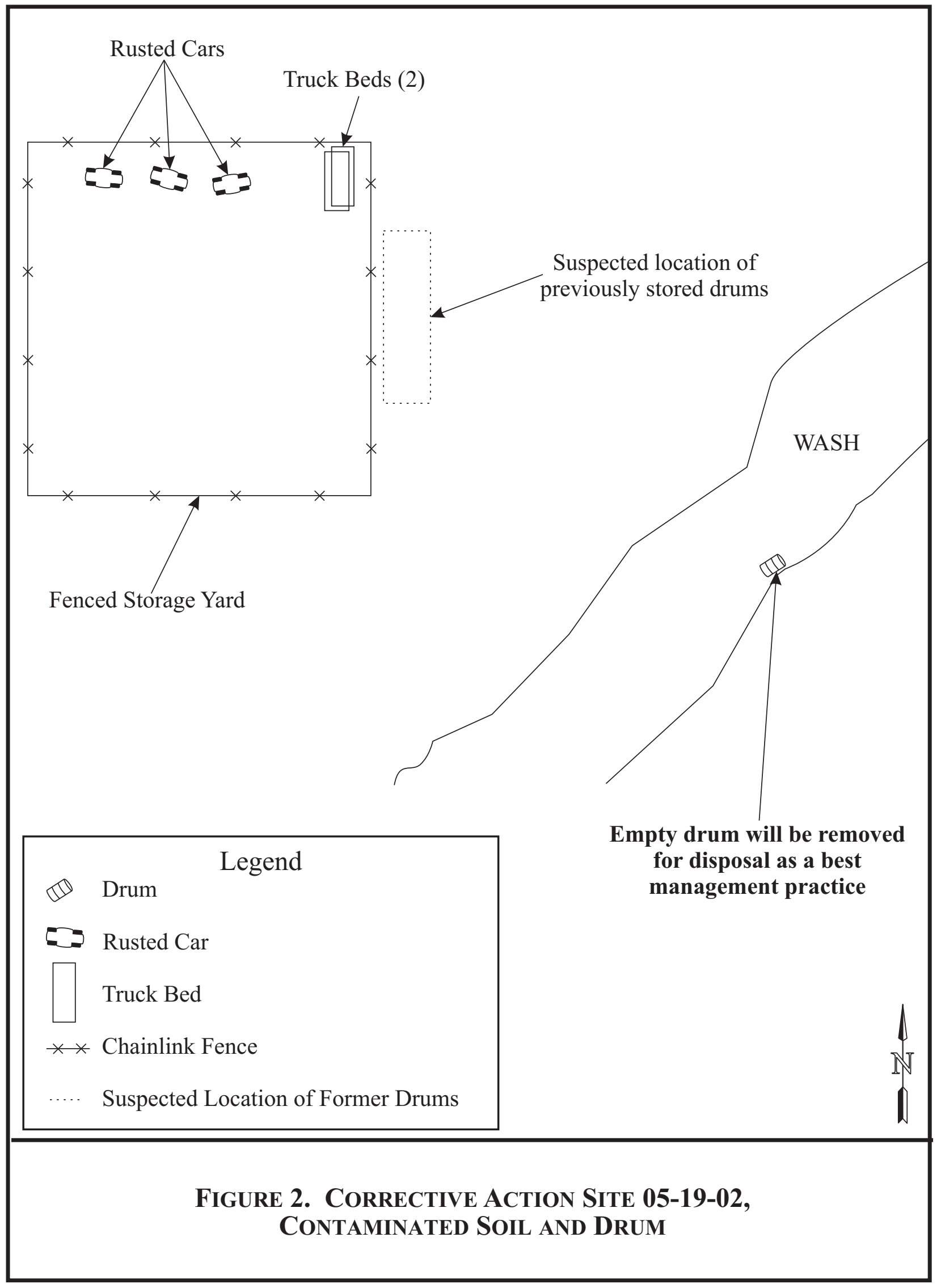




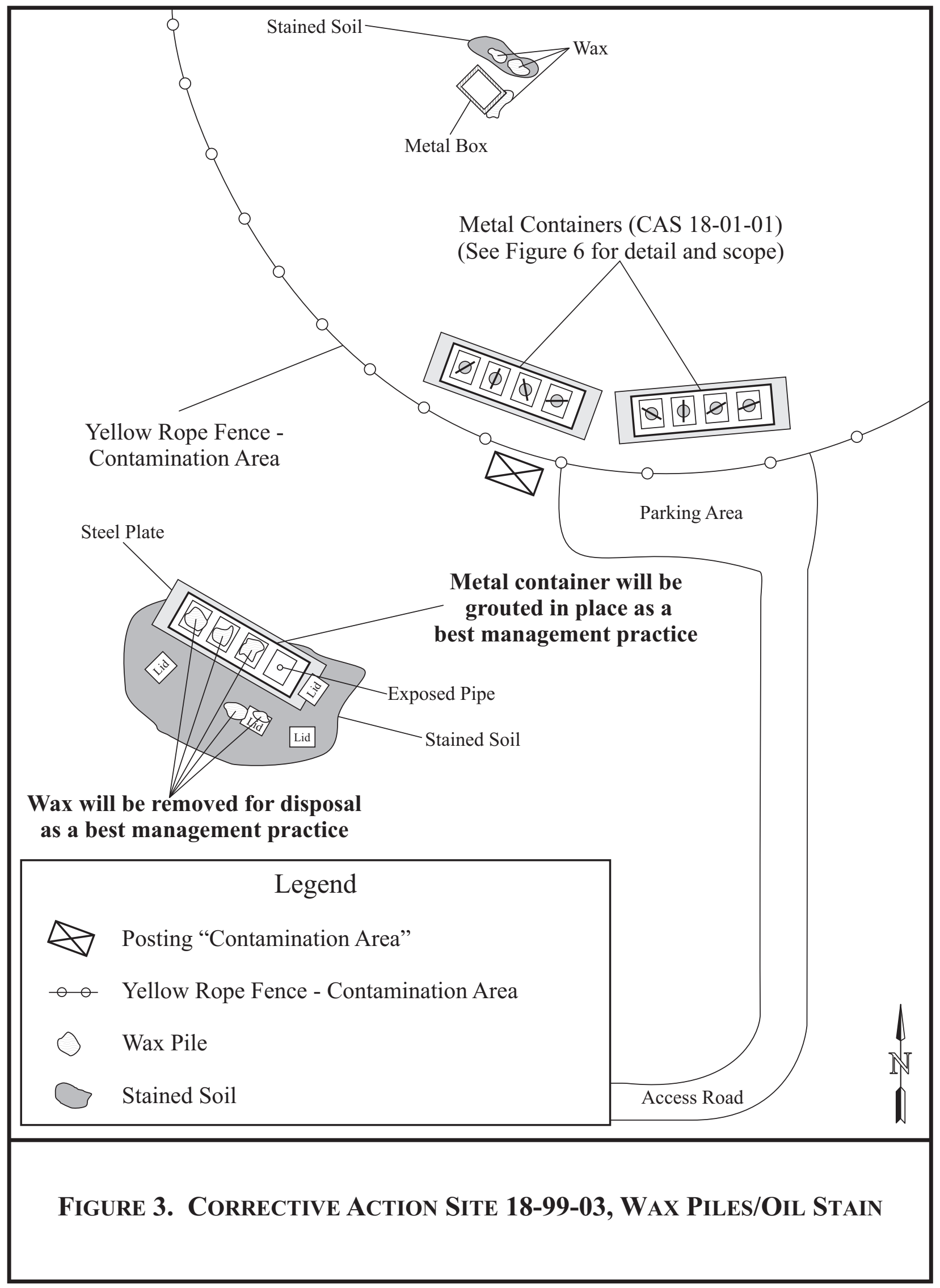


above its FAL of $12.7 \mathrm{pCi} / \mathrm{g}$. The maximum concentration of $\mathrm{Pu}-239 / 240$ was 6,300 pCi/g. Am-241 and Pu-239/240 were also present at concentrations above the FALs in the sample collected from the wax pile located within the CA. All of the samples that exceeded the FALs for radionuclides were collected from within the CA delineating an area of radiological contamination resulting from atmospheric testing. Three reference samples were collected from within the CA but from an area outside of the CAS influence to determine background concentrations of radionuclides. These sample results show that the concentrations of these radionuclides are elevated throughout the area. This contamination was expected and is consistent with contamination found in areas where atmospheric testing occurred. Therefore, Am-241, Pu-238, and Pu-239/240 are not considered COCs for this site. Radiological contamination will be addressed by the Soils Project.

No COCs were identified for this site. No further action is required for this site; however, as a BMP, approximately 2.2 cubic yards ( $\mathrm{yd}^{3}$ ) of wax will be removed (including material from the metal container and the wax pile located outside the CA) for likely disposal as hydrocarbon waste, approximately 30 gallons (gal) of liquid in the metal container will either be removed for disposal as sanitary waste or solidified in place, and the metal container will be grouted in place.

\subsubsection{Alternative 2, Clean Closure}

\subsubsection{Corrective Action Site 02-99-10, D-38 Storage Area}

This site is located in Area 2 of the NTS, southeast of the intersection of Rainier Mesa and 2-07 Roads in the former Area 2 Camp. The camp supported the LLNL drilling and construction activities in the Yucca Flat area. The site consists of a storage yard where various machinery and equipment were stored. Approximately 190 drums containing depleted uranium were also temporarily stored at the site. The depleted uranium was used as counterweights of large cranes used in Project Heavyweight. Lead shot was identified during site characterization activities in three areas. Figure 4 shows a site sketch of the CAS.

TPH was detected in seven characterization soil samples at concentrations above the PAL of $100 \mathrm{mg} / \mathrm{kg}$. The maximum concentration of TPH detected was $300 \mathrm{mg} / \mathrm{kg}$. FALs were established for the hazardous constituents of TPH at their respective PAL concentrations, and none of the hazardous constituents of TPH exceeded the PALs. Therefore, TPH is not considered a COC for this site.

A sample of lead shot was analyzed and found to contain lead and arsenic at concentrations of 860,000 mg/kg and $180 \mathrm{mg} / \mathrm{kg}$, respectively. Therefore, lead and arsenic are considered COCs for this site.

No COCs were identified in the soil at concentrations above FALs at this site; however, approximately 40 gal of lead shot is present at the site that is a potential source of contamination if not removed. The site will be clean closed by removing the lead shot for likely offsite disposal as hazardous waste (HW). 


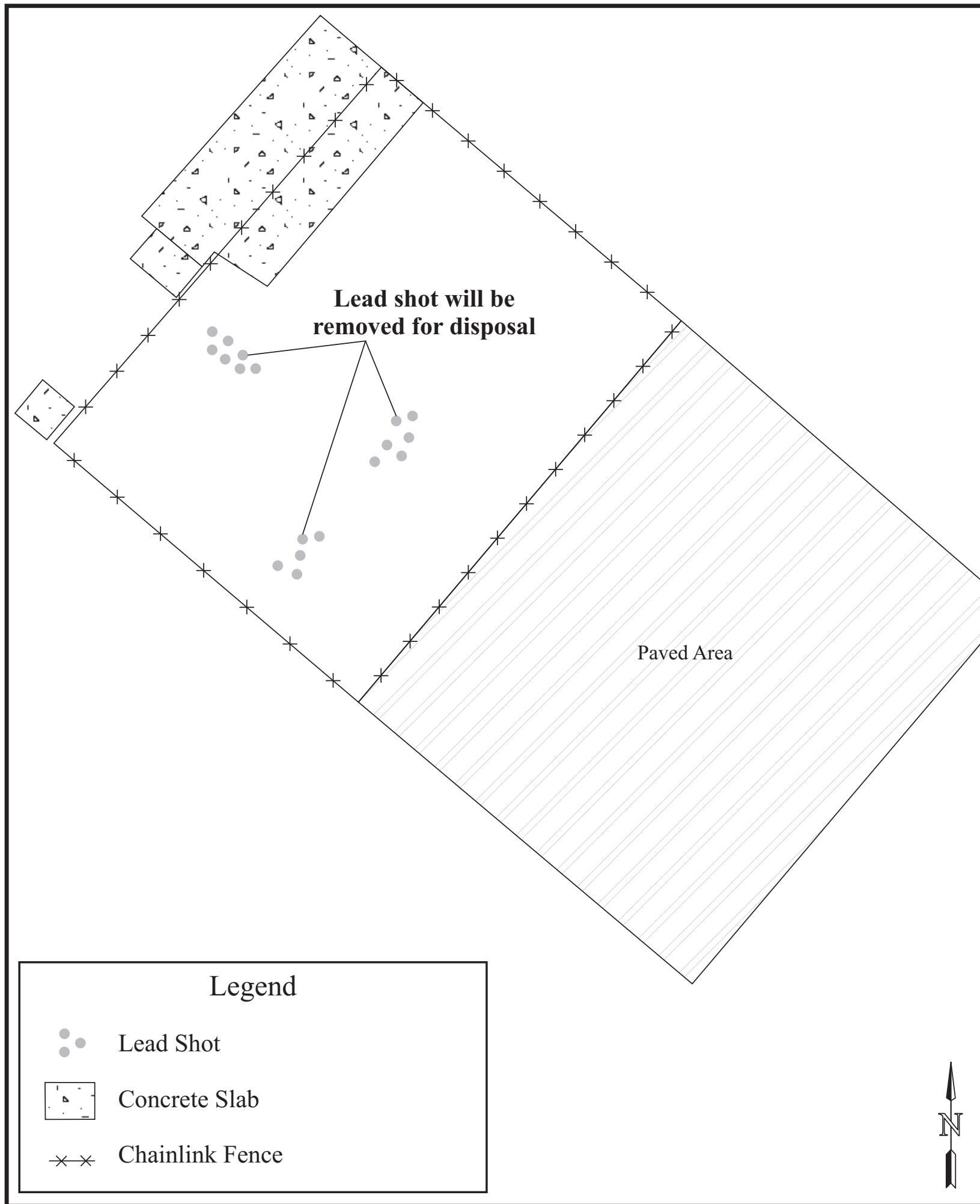

Figure 4. Corrective ACtion Site 02-99-10, D-38 Storage Area 


\subsubsection{Corrective Action Site 03-42-01, Conditional Release Storage Yard}

This site is located in Area 3 of the NTS, east of Mercury Highway on 3-01 Road, south of the Postshot Shop in the former Area 3 Camp. The camp supported the Los Alamos National Laboratory drilling and construction activities in the Yucca Flat area. The site consists of a storage yard where equipment, tanks, piping, portable buildings, and miscellaneous items were stored. A portion of the yard is fenced and posted as a Radioactive Materials Area. Figure 5 shows a site sketch of the CAS.

TPH was detected in twenty-five characterization soil samples at concentrations above the PAL of $100 \mathrm{mg} / \mathrm{kg}$. The maximum concentration of TPH detected was 22,000 mg/kg. FALs were established for the hazardous constituents of TPH at their respective PAL concentrations, and none of the hazardous constituents of TPH exceeded the PALs. Therefore, TPH is not considered a COC for this site.

Am-241 and lead were detected in one characterization soil sample, at location D27, at concentrations above the FALs of $12.7 \mathrm{pCi} / \mathrm{g}$ and $800 \mathrm{mg} / \mathrm{kg}$, respectively. Am-241 and lead were identified at a depth of 0.5 to $1.0 \mathrm{ft}$ bgs. The concentration of Am-241 in the sample was $15 \mathrm{pCi} / \mathrm{g}$. The concentration of lead in the sample was $840 \mathrm{mg} / \mathrm{kg}$. Three samples were collected to bound the lateral extent of the contamination.

The site will be clean closed by removing approximately $5 \mathrm{yd}^{3}$ of soil impacted with Am-241 and lead to a depth of $1.5 \mathrm{ft}$ bgs for likely offsite disposal as mixed waste (MW). A minimum of two verification samples, one from a randomly selected side wall and one from the floor of the excavation, will be collected and analyzed for Am-241 and lead. If verification sample results indicate that an action level is exceeded, additional soil will be removed, and additional verification samples will be collected. Upon verifying that the impacted soil has been removed, the excavation will be backfilled with clean soil and contoured to the approximate surrounding topographic grade.

In addition, as a BMP, asbestos tile will be removed from a portable building, and oil will be removed from three accumulator assemblies. The asbestos and oil will be properly characterized, handled, and disposed. The portable building and assemblies will then be removed for disposal as sanitary waste. In addition, a gas cylinder present at the site will be removed for proper disposal.

\subsubsection{Corrective Action Site 18-01-01, Aboveground Storage Tank}

This site is located near the airstrip in Area 18 of the NTS, southeast of the Little Feller II site. The site consists of two metal containers containing wax and liquid. The containers are believed to be part of the neutron flux experiments associated with the Little Feller II test that took place in 1962. The site is located within a fenced CA. Each container sits on a steel plate and concrete base. Four concrete-encased, closed-ended subsurface pipes extend from the base of each container to between 3.5 and $4.5 \mathrm{ft}$ bgs. There are four circular, twist-off lids on each of the metal containers. Approximately 30 and 600 gal of liquid are present in the eastern and western containers, respectively. Figure 6 shows a site sketch of the CAS. 


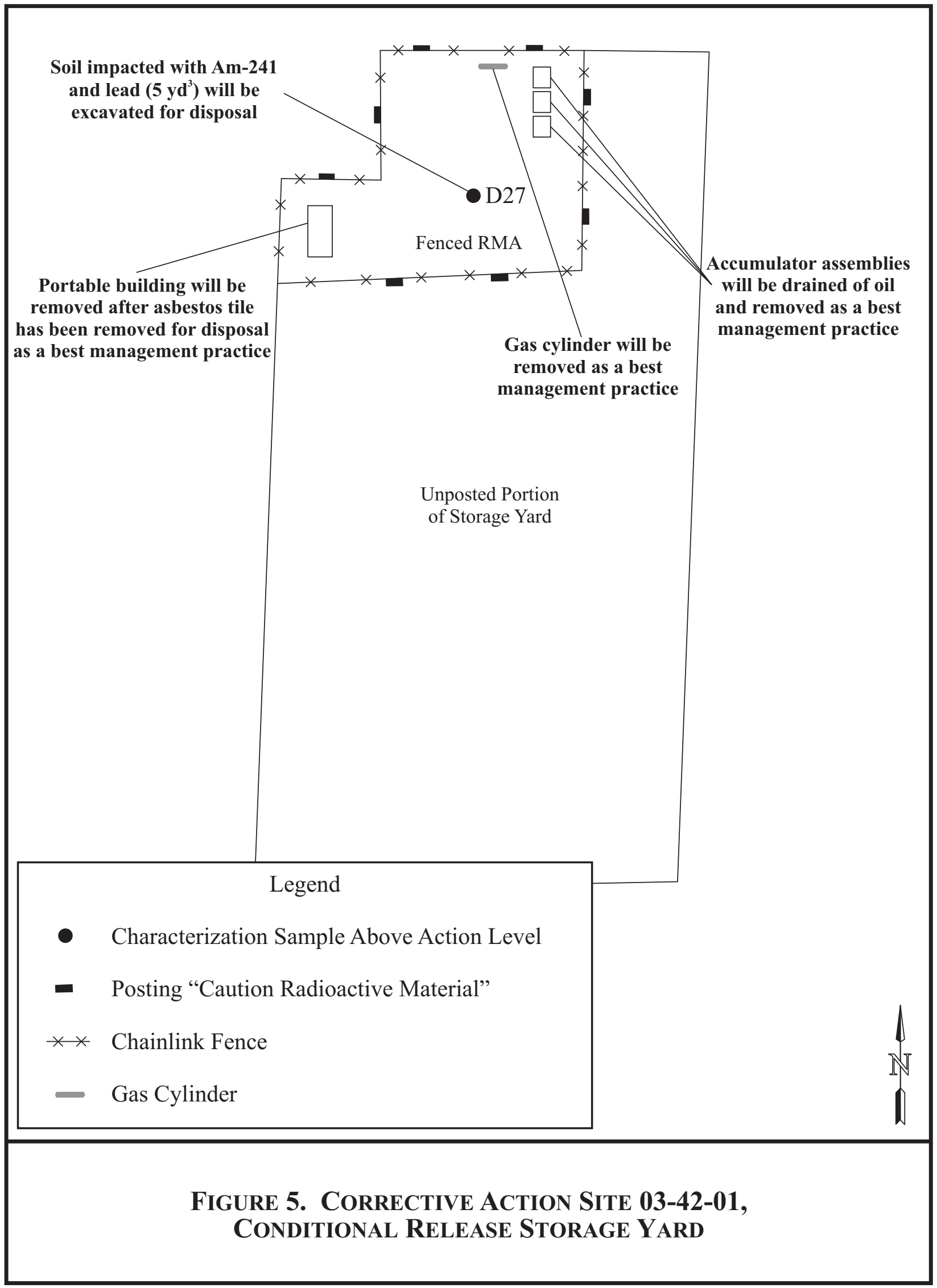




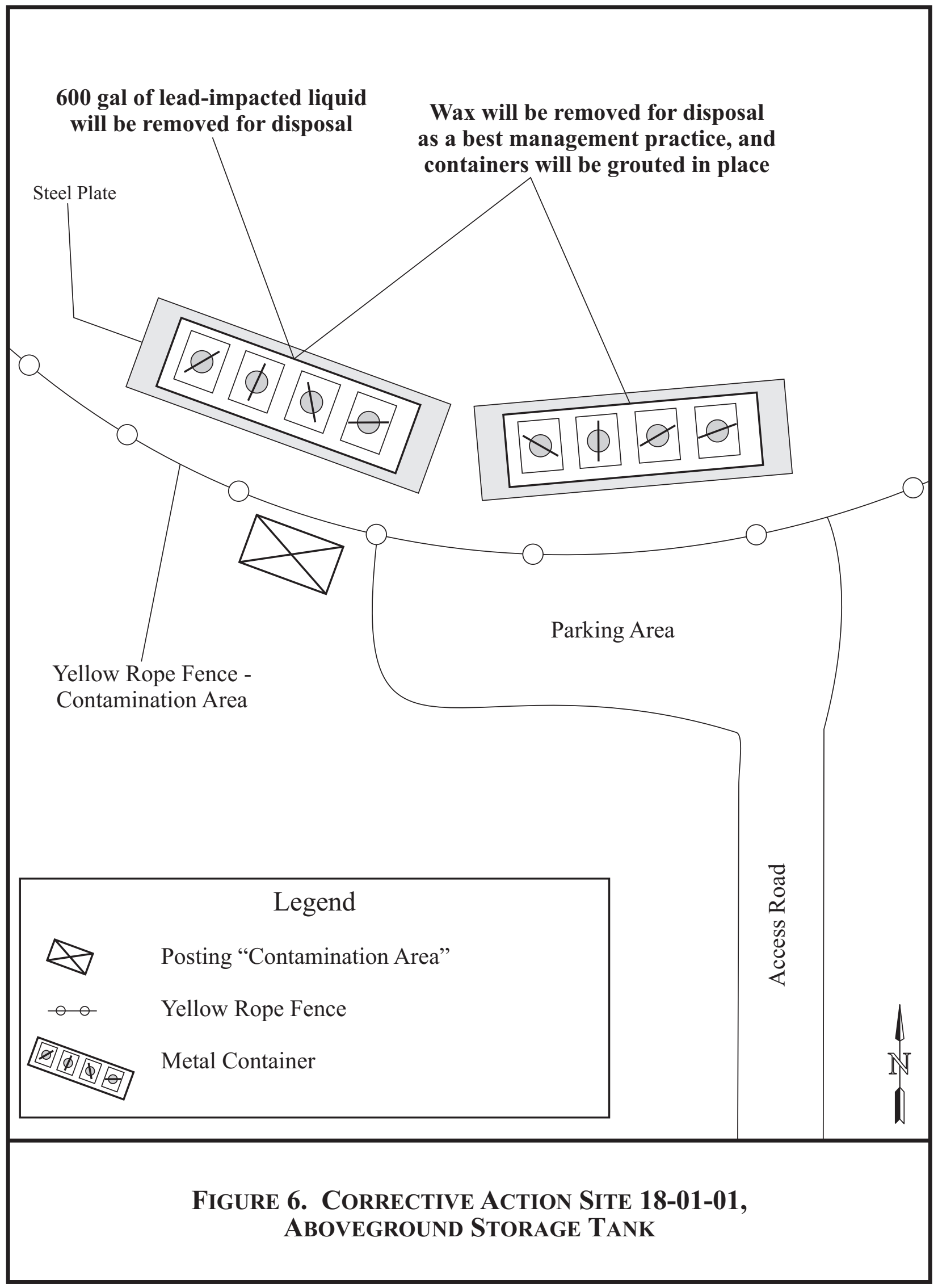


Lead was detected in the characterization sample collected from the liquid in the western metal container at a concentration above the Resource Conservation and Recovery Act toxicity characteristic limit of 5 milligrams per liter (mg/L). The concentration of lead in the sample was $6.5 \mathrm{mg} / \mathrm{L}$. Soil staining was not observed, and lead was not present in the soil samples collected beneath the containers; therefore, lead is limited to the liquid in the western container. No COCs were identified in the liquid in the eastern container.

The site will be clean closed by removing the 600 gal of lead-contaminated liquid from the western container for likely offsite disposal as HW.

In addition, as BMP, approximately $0.4 \mathrm{yd}^{3}$ of wax will be removed from both containers for likely disposal as hydrocarbon waste, approximately 30 gal of liquid in the eastern container will either be removed for disposal as sanitary waste or solidified in place, and the two metal containers will be grouted in place.

\subsection{CONSTRUCTION QUALITY ASSURANCE/QUALITY CONTROL}

Construction activities will include removal of lead shot, soil contaminated with Am-241 and lead, and liquid impacted with lead for proper disposal. In addition, as BMPs, miscellaneous items will be removed and characterized as necessary for proper disposal. No engineered structures will be constructed as part of site closure. Therefore, a construction quality assurance/quality control (QA/QC) plan is not required.

\subsubsection{Construction Field Sample Collection Activities}

Construction field samples are not necessary for the closure of CAU 166. Samples may be collected for the purpose of waste stream characterization and to verify that the approved cleanup criteria have been met. Sample collection activities are addressed in Section 2.4 of this document.

\subsubsection{Construction Laboratory/Analytical Data Quality Indicators}

CAU 166 closure activities are limited to removal of soil, liquid, and debris. Therefore, a construction QA/QC plan is not required, and construction data quality indicators (DQIs) are not applicable. To ensure that backfill material remains consistent, all fill will be taken from an approved borrow source.

\subsection{WASTE MANAGEMENT}

All waste streams will be managed and disposed according to applicable federal and state regulations, U.S. Department of Energy (DOE) Orders, U.S. Department of Transportation (DOT) regulations, and company waste management procedures. CAU 166 closure activities are expected to generate sanitary waste/construction debris, hydrocarbon waste, HW, MW, and asbestos-containing material (ACM). Although not expected, if low-level waste (LLW) and/or Toxic Substances Control Act (TSCA)-regulated waste is generated, it will be properly managed and shipped to an onsite or offsite disposal facility. Confirmation of waste disposal will be included in the CAU 166 Closure Report (CR). 


\subsubsection{Waste Minimization}

All work activities that generate waste will strive to minimize the volume of waste generated. Special care will be taken to properly characterize and segregate waste streams to avoid the generation of additional waste.

\subsubsection{Waste Types}

\subsubsection{Sanitary Waste and Construction Debris}

Sanitary waste (e.g., non-impacted personal protective equipment [PPE] and general trash) and construction debris (e.g., wood, concrete, metal, plastic) removed from sites will be radiologically screened for free release (U.S. Department of Energy, Nevada Operations Office, 2004) and disposed as sanitary waste in an onsite permitted landfill.

\subsubsection{Hydrocarbon Waste}

Hydrocarbon waste may be generated at CAS 18-01-01, Aboveground Storage Tank, and/or CAS 18-99-03, Wax Piles/Oil Stain, in the form of TPH-impacted wax. Hydrocarbon waste generated at CAU 166 will be analyzed for gamma-emitting radionuclides by either the In-Situ Object Counting System or laboratory analysis, if necessary, in order to satisfy the landfill disposal restrictions. Upon receipt of the analytical results, the waste will be properly disposed. Any waste meeting the land disposal restrictions as specified in the landfill permit will be disposed in the Area 6 Hydrocarbon Landfill.

\subsubsection{Hazardous Waste}

Closure activities are expected to generate HW at CAS 02-99-10, D-38 Storage Area, in the form of lead shot, and at CAS 18-01-01, Aboveground Storage Tank, in the form of lead-impacted liquid. The waste will be characterized by process knowledge and/or laboratory analysis, and a waste profile for disposal will be prepared. All HW will be managed and disposed according to all applicable federal and state regulations, DOE Orders, DOT regulations, and company waste management procedures. Upon generation, $\mathrm{HW}$ will be containerized and stored in a satellite accumulation area or a 90-day HW accumulation area, depending on the amount of waste generated. After an approved waste profile is generated, the waste will be disposed at a permitted offsite treatment, storage, and disposal facility.

\subsubsection{Mixed Waste}

MW is waste containing both radioactive waste and HW constituents. Closure activities are expected to generate MW at CAS 03-42-01, Contaminated Release Storage Yard, in the form of soil impacted with Am-241 and lead. The waste will be managed and disposed according to all applicable federal and state regulations, DOE Orders, DOT regulations, and company waste management procedures. All MW will be packaged under the guidance of a Waste Certification Official and Waste Generator Services personnel. When staged onsite, the MW will be stored in a radioactive materials area and a 90-day HW accumulation area until a waste disposal profile is prepared and approved. Samples will be collected to enable completion of a treatability study, if necessary. The MW will then be disposed of appropriately. 


\subsubsection{Asbestos-Containing Material}

Closure activities are expected to generate ACM at CAS 03-42-01, Conditional Release Storage Yard, in the form of asbestos tile. All ACM will be removed by trained and licensed asbestos workers and handled and disposed according to all applicable federal and state regulations, DOE Orders, DOT regulations, and company waste management procedures.

\subsubsection{Low-Level Waste}

Closure activities are not expected to generate LLW; however, if generated, LLW will be managed and disposed according to all applicable federal and state regulations, DOE Orders, DOT regulations, and company waste management procedures. All LLW will be packaged under the guidance of a Waste Certification Official and Waste Generator Services personnel. LLW will be stored in a radioactive materials area until a waste disposal profile is prepared and approved, and transport to an appropriate disposal facility can be arranged.

\subsubsection{Toxic Substances Control Act-Regulated Waste}

Closure activities are not expected to generate TSCA-regulated waste; however, if generated, TSCA-regulated waste will be managed and disposed according to all applicable federal and state regulations, DOE Orders, DOT regulations, and company waste management procedures. After an approved waste profile is generated, the waste will be disposed at an appropriate TSCA-regulated disposal facility.

\subsubsection{Decontamination Waste}

All radiologically impacted equipment will be surveyed prior to release from an exclusion zone. Any equipment that becomes contaminated during closure activities will be decontaminated onsite. Dry decontamination will be the preferred method. For larger pieces of equipment that cannot be effectively decontaminated using dry decontamination techniques, wet decontamination techniques will be used. All decontamination rinsate will be managed appropriately according to applicable regulations and, once characterized, properly disposed.

\subsubsection{Personal Protective Equipment}

All PPE that becomes contaminated during closure activities will be disposed with the appropriate waste stream.

\subsection{CONFIRMATION OF CORRECTIVE ACTIONS}

Accurate and defensible analytical data will be collected to characterize waste and verify that the closure objectives are met. In addition, visual inspection and photographic documentation will verify final site conditions. 


\subsubsection{No Further Action Sites}

No work will be performed at the following sites, and confirmation of corrective action will not be required:

- CAS 02-42-01, Cond. Release Storage Yd - North

- CAS 02-42-02, Cond. Release Storage Yd - South

No further action is required at the following sites; however, BMPs will be performed, and the final site conditions will be verified by visual inspection and photographic documentation included in the CR:

- CAS 05-19-02, Contaminated Soil and Drum

- CAS 18-99-03, Wax Piles/Oil Stain

\subsubsection{Clean Closure Sites}

The following sites will be clean closed:

- CAS 02-99-10, D-38 Storage Area

- CAS 03-42-01, Conditional Release Storage Yard

- CAS 18-01-01, Aboveground Storage Tank

Closure activities at CAS 02-99-10 will be verified by visual inspection and photographic documentation of removal of lead shot. CAS 03-42-01 will be considered clean closed after laboratory results verify that verification samples are below the applicable action levels. BMPs at CAS 03-42-01 will be verified by visual inspection and photographic documentation of removal of debris and other items. Closure activities at CAS 18-01-01 will by verified by visual inspection and photographic documentation of removal of wax and lead-impacted liquid, and grouting of metal containers. Confirmation of corrective actions will be included in the CR.

\subsubsection{Sample Collection Methods}

All soil verification samples will be collected by qualified personnel using standard sampling procedures. Sample collection date, time, and other pertinent information will be logged on a "Service Request and Chain of Custody Record," and recorded in a bound project field notebook. Samples will be collected by hand, using disposable pre-cleaned or decontaminated sampling equipment. All samples will be collected in clean containers, labeled with a unique sample identification number using the CAS number followed by the sample number (e.g., 034201-V1), sealed with a tamper-proof seal, bagged, placed on ice in a cooler, and transported to an offsite analytical laboratory following strict chain of custody. Samples will be analyzed by U.S. Environmental Protection Agency (EPA)-approved analytical methods at EPA-approved laboratories (EPA, 1996). Sample analysis will include laboratory analysis of QA/QC samples and will follow stringent QA/QC procedures (EPA, 1996). Sample analysis for radioisotopes will be performed in accordance with Environmental Measurements Laboratory Procedures Manual (DOE, 1997).

One set of QA/QC samples will be collected for every twenty environmental samples or with every batch of samples submitted for laboratory analysis, whichever is greater. QA/QC samples will include blind duplicates, matrix spike/matrix spike duplicates, and equipment rinsate samples. All blind duplicates will be labeled with a unique sample number. All samples will be 
collected according to the Industrial Sites Quality Assurance Project Plan (U.S. Department of Energy, National Nuclear Security Administration Nevada Operations Office [NNSA/NV], 2002).

\subsubsection{Laboratory/Analytical Data Quality Indicators}

Data quality objectives (DQOs) are qualitative and quantitative statements that specify the quality of the data required supporting closure of a site.

CAS 03-42-01, Conditional Release Storage Yard, will require the collection and analysis of verification samples. If it is required, waste characterization samples will be collected for disposal purposes. All laboratory data generated during closure activities will be reviewed by project personnel to ensure the data are usable and complete according to the CAU 166 DQOs. In addition, as specified in the Industrial Sites Quality Assurance Project Plan (NNSA/NV, 2002), 100 percent of the data packages will be evaluated at the Tier I and Tier II levels. Any data determined not to be valid will be identified in the CR.

DQIs are qualitative and quantitative statements that specify the data requirements of a project. The DQIs include precision, accuracy, representativeness, comparability, completeness, and sensitivity. These DQIs are discussed below.

\subsubsection{Precision}

Precision is a measure of agreement among a replicate set of measurements of the same property under similar conditions. This agreement is expressed as the relative percentage difference (RPD) between duplicate measurements. Precision applies to parameters sampled and analyzed in duplicate.

One duplicate sample will be collected per set of twenty or fewer verification samples. All duplicate samples will be collected from the same medium and analyzed for the same set of analytes. The precision of the analytical results will be assessed by calculating the RPD for a verification sample and its duplicate sample results. (An RPD of less than or equal to 30 percent indicates acceptable precision [NNSA/NV, 2002]).

\subsubsection{Accuracy}

Accuracy is a measure of the closeness of an individual measurement or the average of a number of measurements to the true value. Accuracy includes a combination of random error (precision) and systematic error (bias) components that result from sampling and analytical operations. This closeness is expressed as percent recovery (\%R). Accuracy will be assessed by examining the $\% \mathrm{R}$ of laboratory control and spiked samples. (A \%R within the range of 70 to 130 percent indicates satisfactory analytical accuracy [NNSA/NV, 2002]).

\subsubsection{Representativeness}

Representativeness is a qualitative evaluation of measurement system performance. It is the degree to which sample data accurately and precisely represent a characteristic of a population, parameter variations at a sampling point, or an environmental condition. Representativeness will be attained by ensuring that the sample locations, analytical parameters, analytical methods, sampling protocols, and sample handling all meet the project-specific objectives. 


\subsubsection{Comparability}

Comparability is a qualitative measure that expresses the confidence that one data set can be compared to another. It will be achieved by using standardized field sampling procedures. The same analytical laboratory will perform the same analyses for all samples. Sample results will be reported in standard units to allow for comparison of the data.

\subsubsection{Completeness}

Completeness is a quantitative measure of data quality expressed as the percentage of valid data obtained that satisfies the project-specific requirements. Since a limited number of samples will be collected for both waste characterization and verification of closure, 100 percent of the data collected needs to be of acceptable quality to maintain acceptable QA/QC standards.

\subsubsection{Sensitivity}

Sensitivity is the capability of a method or instrument to discriminate between measurement responses representing different levels of a variable of interest. This indicator is determined from the value of the standard deviation at the concentration level of interest. It represents the minimum difference of concentration that can be distinguished between two samples with a high degree of confidence. Sensitivity must be sufficient to detect contaminants at or below decision levels. Sensitivity will be achieved by analyzing all samples using appropriate EPA-approved analytical laboratories, methods, and instruments.

\subsection{Permits}

Prior to beginning field closure activities, planning documents and permits will be prepared. These documents will include a National Environmental Policy Act (NEPA) Checklist, a Real Estate/Operations Permit (REOP), Radiological Work Permits (RWPs), excavation permits, and blind penetration permits.

\subsubsection{National Environmental Policy Act Checklist}

A NEPA Checklist will be completed prior to all closure activities at the site. Closure activities will follow all applicable federal, state, and local laws, regulations, and permits regarding protection of the environment.

\subsubsection{Real Estate/Operations Permit}

A REOP will be obtained prior to beginning closure activities. The permit will establish NNSA/NSO as the prime authority possessing control of the site.

\subsubsection{Radiological Work Permit}

RWPs will be required for work at any radiologically impacted site when radiological conditions require, as determined by Health Physics. RWPs will inform workers of the specific PPE necessary to protect them while performing their tasks and identify site-specific controls. The workers will be required to sign the RWPs and acknowledge their understanding of the requirements before entry into any radiologically controlled area, if present. The RWPs will be 
maintained by the Radiological Control Technician at the entrance to the radiologically controlled area. All site workers will be required to be Radiation Worker II-trained to perform work within a radiologically controlled area.

\subsubsection{Utility Clearances, Excavation Permits, and Blind Penetration Permits}

An excavation permit and a blind penetration permit will be obtained prior to beginning

excavation activities. These permits require that a utility clearance be performed. A copy of the permit will be filed onsite throughout the duration of the project. 


\subsection{SCHEDULE}

All preparation and field activities are scheduled for completion in fiscal year 2008. Sufficient flexibility will be incorporated into the field schedule to allow for minor difficulties

(e.g., weather, equipment failure). NNSA/NSO shall notify NDEP of any condition or event that may impact the project schedule. 
CAU 166 CAP

Section: Schedule

Revision: 0

Date: October 2007

THIS PAGE INTENTIONALLY LEFT BLANK 


\subsection{POST-CLOSURE PLAN}

None of the CASs in CAU 166 require closure in place with administrative controls. Use restrictions will not be implemented, and post-closure inspections will not be required.

\subsection{INSPECTIONS}

Post-closure inspections will not be required for CAU 166.

\subsection{MONITORING}

Post-closure monitoring will not be required for CAU 166.

\subsection{MAINTENANCE AND REPAIR}

Post-closure maintenance and repair will not be required for CAU 166. 
CAU 166 CAP

Section: Post-Closure Plan

Revision: 0

Date: October 2007

THIS PAGE INTENTIONALLY LEFT BLANK 


\subsection{REFERENCES}

DOE, see U.S. Department of Energy.

EPA, see U.S. Environmental Protection Agency.

Federal Facility Agreement and Consent Order. 1996 (as amended August 2006). Agreed to by the State of Nevada; the U.S. Department of Energy, Environmental Management; the U.S. Department of Defense; and the U.S. Department of Energy, Legacy Management.

FFACO, see Federal Facility Agreement and Consent Order.

NNSA/NSO, see U.S. Department of Energy, National Nuclear Security Administration Nevada Site Office.

NNSA/NV, see U.S. Department of Energy, National Nuclear Security Administration Nevada Operations Office.

U.S. Department of Energy. 1997. Environmental Measurements Laboratory Procedures Manual, HASL-300, $28^{\text {th }}$ Ed., Vol. 1. New York, NY.

U.S. Department of Energy, National Nuclear Security Administration Nevada Operations Office. 2002. Industrial Sites Quality Assurance Project Plan, Nevada Test Site, Nevada, Revision 3, DOE/NV--372. Las Vegas, NV.

U.S. Department of Energy, National Nuclear Security Administration Nevada Site Office. 2006. Corrective Action Investigation Plan for Corrective Action Unit 166: Storage Yards and Contaminated Materials, Nevada Test Site, Nevada, DOE/NV--1127. Las Vegas, NV.

U.S. Department of Energy, National Nuclear Security Administration Nevada Site Office. 2007. Corrective Action Decision Document for Corrective Action Unit 166: Storage Yards and Contaminated Materials, Nevada Test Site, Nevada, DOE/NV--1188. Las Vegas, NV.

U.S. Department of Energy, Nevada Operations Office. 2004. NV/YMP Radiological Control Manual, DOE/NV/11718--079-REV 5. Las Vegas, NV.

U.S. Environmental Protection Agency. 1996. Test Methods for Evaluating Solid Waste Physical/Chemical Methods, SW-846, Third Edition. Washington, D.C. 
CAU 166 CAP

Section: References

Revision: 0

Date: October 2007

THIS PAGE INTENTIONALLY LEFT BLANK 


\section{APPENDiX A.1}

\section{ENGINEERING SPECIFICATION AND DRAWINGS}

NOTE: Engineering specifications and drawings are not required for closure of CAU 166. This Appendix is included here as required by the approved Federal Facility Agreement and Consent Order outline for a Corrective Action Plan. 
CAU 166 CAP

Section: Appendix A.1

Revision: 0

Date: October 2007

THIS PAGE INTENTIONALLY LEFT BLANK

A.1-2 


\section{ApPendix A.2}

\section{SAMPling AND ANALYSis Plan}

NOTE: Sufficient details on the type, number, and location of verification samples to be collected to verify site closure activities have been provided in Sections 2.1.2 and 2.4 of this document. Additionally, sufficient details on waste characterization samples to be collected have been provided in Section 2.1 and 2.4. This Appendix is included here as required by the approved Federal Facility Agreement and Consent Order outline for a Corrective Action Plan. 
CAU 166 CAP

Section: Appendix A.2

Revision: 0

Date: October 2007

THIS PAGE INTENTIONALLY LEFT BLANK

A.2-2 
CAU 166 CAP

Section: Appendix A.3

Revision: 0

Date: October 2007

\section{ApPendix A.3}

\section{Project Organization}


CAU 166 CAP

Section: Appendix A.3

Revision: 0

Date: October 2007

THIS PAGE INTENTIONALLY LEFT BLANK

A.3-2 
For this project, the U.S. Department of Energy, National Nuclear Security Administration Nevada Site Office (NNSA/NSO) points of contact are as follows:

NNSA/NSO Federal Industrial Sites Sub-Project Director: Kevin J. Cabble

Telephone Number: (702) 295-5000

NNSA/NSO Task Manager: Sabine T. Curtis

Telephone Number: (702) 295-0542

The identification of the project Health and Safety Officer and the Quality Assurance Officer can be found in the appropriate plan. However, personnel are subject to change, and it is suggested that the appropriate U.S. Department of Energy Project Manager be contacted for further information. The Task Manager will be identified in the Federal Facility Agreement and Consent Order Monthly Activity Report prior to the start of field activities. 
CAU 166 CAP

Section: Appendix A.3

Revision: 0

Date: October 2007

THIS PAGE INTENTIONALLY LEFT BLANK

A.3-4 
CAU 166 CAP

Section: Library Distribution List

Revision: 0

Date: October 2007

\section{LIBRARY DISTRIBUTION LIST}


CAU 166 CAP

Section: Library Distribution List

Revision: 0

Date: October 2007

THIS PAGE INTENTIONALLY LEFT BLANK 
U.S. Department of Energy

National Nuclear Security Administration

Nevada Site Office

Technical Library

P.O. Box 98518, M/S 505

Las Vegas, NV 89193-8518

U.S. Department of Energy

Office of Scientific and Technical Information

P.O. Box 62

Oak Ridge, TN 37831-0062

Southern Nevada Public Reading Facility

c/o Nuclear Testing Archive

P.O. Box 98521, M/S 400

Las Vegas, NV 89193-8521

Manager, Northern Nevada FFACO

Public Reading Facility

c/o Nevada State Library \& Archives

Carson City, NV 89701-4285
1 (Uncontrolled, electronic copy)

1 (Uncontrolled, electronic copy)

2 (Uncontrolled, electronic copies)

1 (Uncontrolled, electronic copy) 
CAU 166 CAP

Section: Library Distribution List

Revision: 0

Date: October 2007

THIS PAGE INTENTIONALLY LEFT BLANK 